\title{
On the Influence of Immersion in certain Electrolytes upon Cells of Saxifraga umbrosa.
}

BY

\author{
MAUD WILLIAMS, B.SC. \\ With three Figures in the Text.
}

T $N$ earlier work (1) upon this subject strips from the upper side of the 1 leaf-stalk of Saxifraga umbrosa were immersed in electrolytes of known concentrations and the times of immersion required to produce a certain arbitrary change determined. The cells in question are rich in tannin, and over a long period are impermeable to weak ferric chloride solution, so that undamaged cells do not show the blue coloration due to reaction of tannin and iron chloride when the sections are mounted in the latter solution. When, however, immersion in the electrolytes studied had been prolonged sufficiently the nature of the protoplasm was found to be so modified that the ferric chloride diffused it, and it was possible to obtain blue tinting and later a precipitate. In the experiments already recorded immersion in the electrolyte was continued until it was found possible to produce the ferric chloride reaction (using 0.2 per cent.) when the sections were soaked in the reagent for three minutes.

The experiments showed that all the solutions studied produced this change if the time of immersion were sufficiently prolonged, and there was evidence for a definite connexion between time required and the concentration employed. Over the limited range of time and concentration it appeared that the following formula held for a particular electrolyte:

where $T=$ time required,

$$
\log T+k \overline{(\log C}+\mathrm{I})=\text { constant }
$$

$C=$ concentration in gram-mols. per litre, and the constant depended upon the electrolyte. of view.

These experiments were open to criticism from several points

I. The experiments had been carried out at room temperature and no corrections were possible for fluctuations.

2. It had not been determined whether the change in the protoplasm was of a reversible nature or whether permanent injury had resulted.

3. The effect of the ferric chloride upon the protoplasm had not been studied beyond the fact that the solution alone took several hours to enter

[Annals of Botany, Vol. XXXVI. No. CXLIV. October, 1922.] 
healthy cells. Since the iron salt used was one liable to hydrolyse, further study would have been advisable.

After the results had been published it was found that the formula agreed with one already derived by other workers for definite measures of change in the case of bacteria (2) and unicellular Algae (3). The additional interest of this similarity led to the decision to repeat and extend the work, using a more stable reagent for testing the change in the protoplasm and carrying out all immersions at a fixed temperature.

\section{Choice of Reagent.}

Search was-made for a reagent which would prove a delicate test for tannin and at the same time would be stable in dilute solution. Dekker (4), in his work on tannins, recommends a 5 per cent. solution of potassium dichromate for staining purposes.

It was found that in the particular cells studied a solution of $0 \cdot$ I per cent. was sufficient to produce a definite precipitate in a period of three minutes when the cells had previously been rendered permeable. This very dilute solution was also suitable for sections studied under the ultra-microscope, as the first-formed particles came down with well-marked Brownian movement. The next step was to find whether this weak solution was stable. This was done by a series of measurements of the resistance when a conductivity cell was filled with the solution and the whole kept in a thermostat at $25^{\circ} \mathrm{C}$. The measurements were made by the 'metre bridge' method, a commutator and galvanometer being employed. The readings were taken at different times extending over forty-two days; for each date the mean of three determinations was taken. The values given in Table I showed a variation of only I per cent., so that the solution was considered free from objection.

All the tests on the plant material necessary in the work given below were made with solutions prepared from the same sample of crystals as those used in the conductivity tests.

The influence of various concentrations of the potassium dichromate upon the cell had next to be studied. The plant material, treated as for the rest of the immersions, was placed in tubes containing 30 c.c. of the solution and kept in a thermostat at $25^{\circ} \mathrm{C}$. In each concentration the time was found when a clearly defined precipitate first appeared in the cells. The results are shown in Table II, and indicate that this salt has a 'time and concentration' connexion of the same type as that already mentioned, but that the influence of a $\circ \cdot I$ per cent. solution, acting upon the cell for three minutes, is negligible.

The effect of changing the temperature of immersion was also studied for the same salt, a 3 per cent. solution being chosen. The readings for time required and temperature are given in Table III and Fig. I. Only 
one experiment was carried out at $9^{\circ} \mathrm{C}$. owing to the difficulty of maintaining a steady temperature by the means available, viz. the addition of small quantities of ice-cold water to the thermostat of tap-water. The tempera-

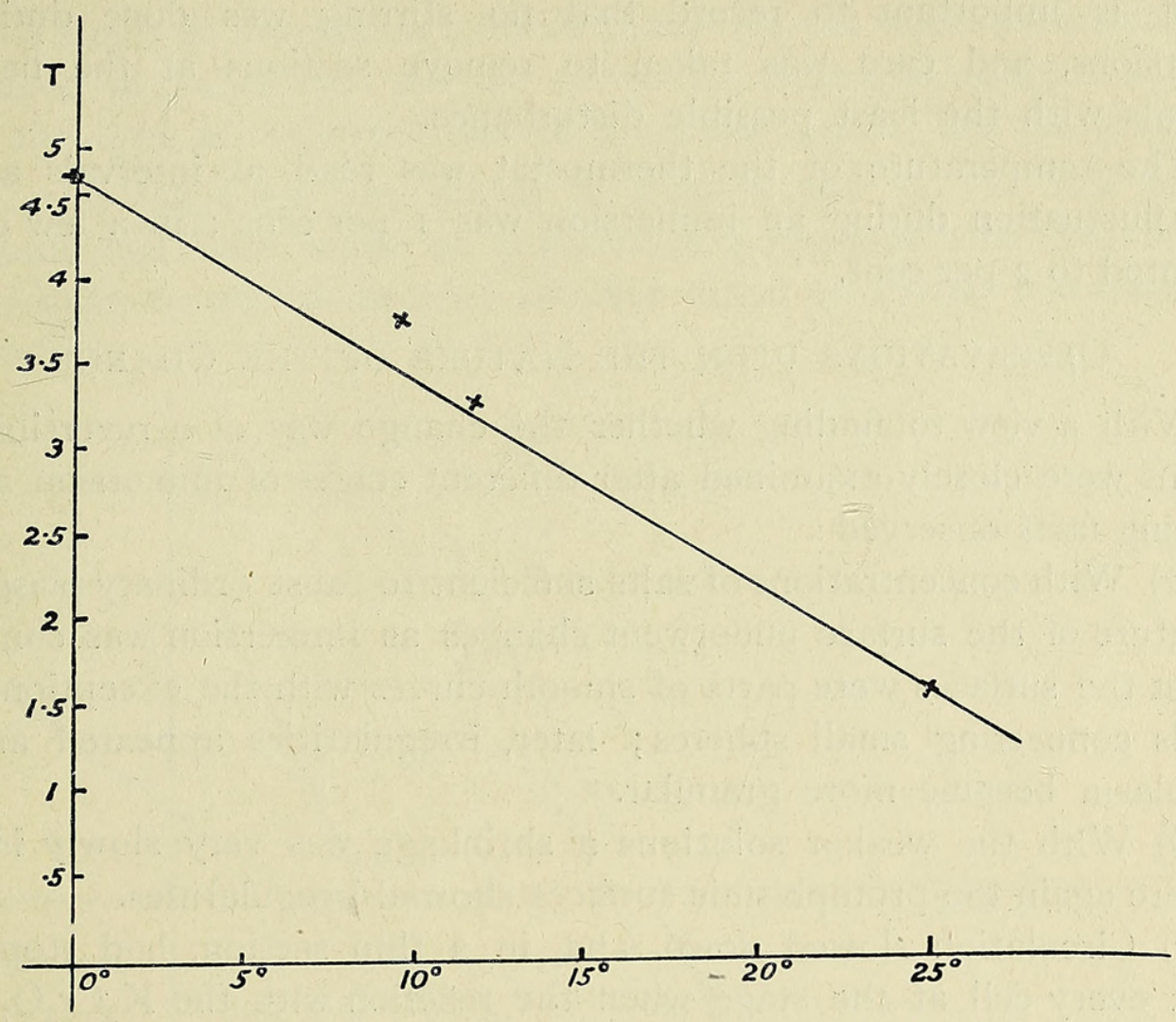

FIG. 1. Influence of change of temperature upon permeability to $\mathrm{K}_{2} \mathrm{Cr}_{2} \mathrm{O}_{7}$. Concentration $=3 \%$. $T=$ time in hours to produce precipitate.

ture effect showed the advisability of keeping strictly to one value throughout the tests, although the errors due to slight fluctuations of the room temperature in earlier work were probably small compared with those due to 'past history' factors.

\section{Preliminary Treatment of Material and ImMersions.}

The plants used for this portion of the work were all grown in the same soil. For winter use specimens were kept in a cool greenhouse and rosettes cut and kept in water in the laboratory for one day before the sections were made. Long strips were torn from the petiole and kept for twenty-four hours in a large quantity of distilled water, which was changed at intervals. It was found to be extremely important to select leaves of the same condition, and those from the base and apex had to be rejected. Doubtless the differences in the cell-walls modified diffusion. On account of lack of similar material in two or three of the tests quoted it will be found that fewer values than the usual number had to suffice.

On preliminary examination of the material with I per cent. caffeine it was found that a greater number of cells had tannin contents than had 
been the case in the plants from another source used in the earlier work; consequently in the $\mathrm{K}_{2} \mathrm{Cr}_{2} \mathrm{O}_{7}$ tests a general appearance of precipitate was sought.

It is important to record that no stirring was done during the immersions, and care was taken to remove sections at the necessary intervals with the least possible disturbance.

The temperature of the thermostat was read at intervals and the usual fluctuation during an immersion was I per cent.; in a few cases it amounted to 2 per cent.

\section{Observations upon the Nature of the Change.}

With a view to finding whether the change was of a reversible type, sections were closely examined after different stages of immersion and the following facts observed :

(a) With concentrations of salts sufficient to cause ordinary plasmolysis the nature of the surface underwent changes as immersion was continued. At first the surfaces were parts of smooth curves with the exception of the threads connecting small spheres; later, irregularities appeared and the protoplasm became more granular.

(b) With the weaker solutions a shrinkage was very slowly induced, and here again the protoplasmic surfaces showed irregularities.

(c) Circulation slowed down, and, in a thin section, had stopped in almost every cell at the stage ${ }^{-}$when the reaction with the $\mathrm{K}_{2} \mathrm{Cr}_{2} \mathrm{O}_{7}$ could be obtained.

(d) Sections immersed for the critical times did not recover their circulatory power or normal appearance upon even prolonged treatment with distilled water.

Further examination was carried out with the 'dark field' illumination produced by a paraboloid condenser. Material immersed for the critical times in $\mathrm{KI}$ or in $\mathrm{KCl}$ was used in these tests. Before immersion the sections showed, against the black field, light scattered from their cellwalls and from chloroplastids, very faint light scattered from the general protoplasm, and some bright particles, difficult to focus, near the surface of the protoplasm. These particles possessed Brownian movement.

With the same focus it was seen after immersion that movement had stopped, but there was much more general diffusion of light, denoting a state of greater aggregation. No further change was observed when the sections were left in distilled water.

When the $\mathrm{K}_{2} \mathrm{Cr}_{2} \mathrm{O}_{7}$ was applied, particles in Brownian movement appeared in the corners of the cells as well as in connexion with the plasmolysed masses.

These facts, taken collectively, show that immersion for the critical time produces an irreversible change and the material may be said to be 
'poisoned'; moreover, at the time the potassium dichromate is able to penetrate the protoplasm the tannin is able to diffuse out of the vacuole.

\section{RESUlTS.}

The times of immersion (critical times) for the various concentrations are quoted in Table IV. As the curves for time and concentrations all follow the type already recorded they are not drawn, but the graphs for $\log T$ and $\log C+I$ are shown in Figs. 2 and 3 . It will be seen that study has been made of a series of potassium salts and of three sodium salts, to try to discover whether anion or kation determines the relationship.

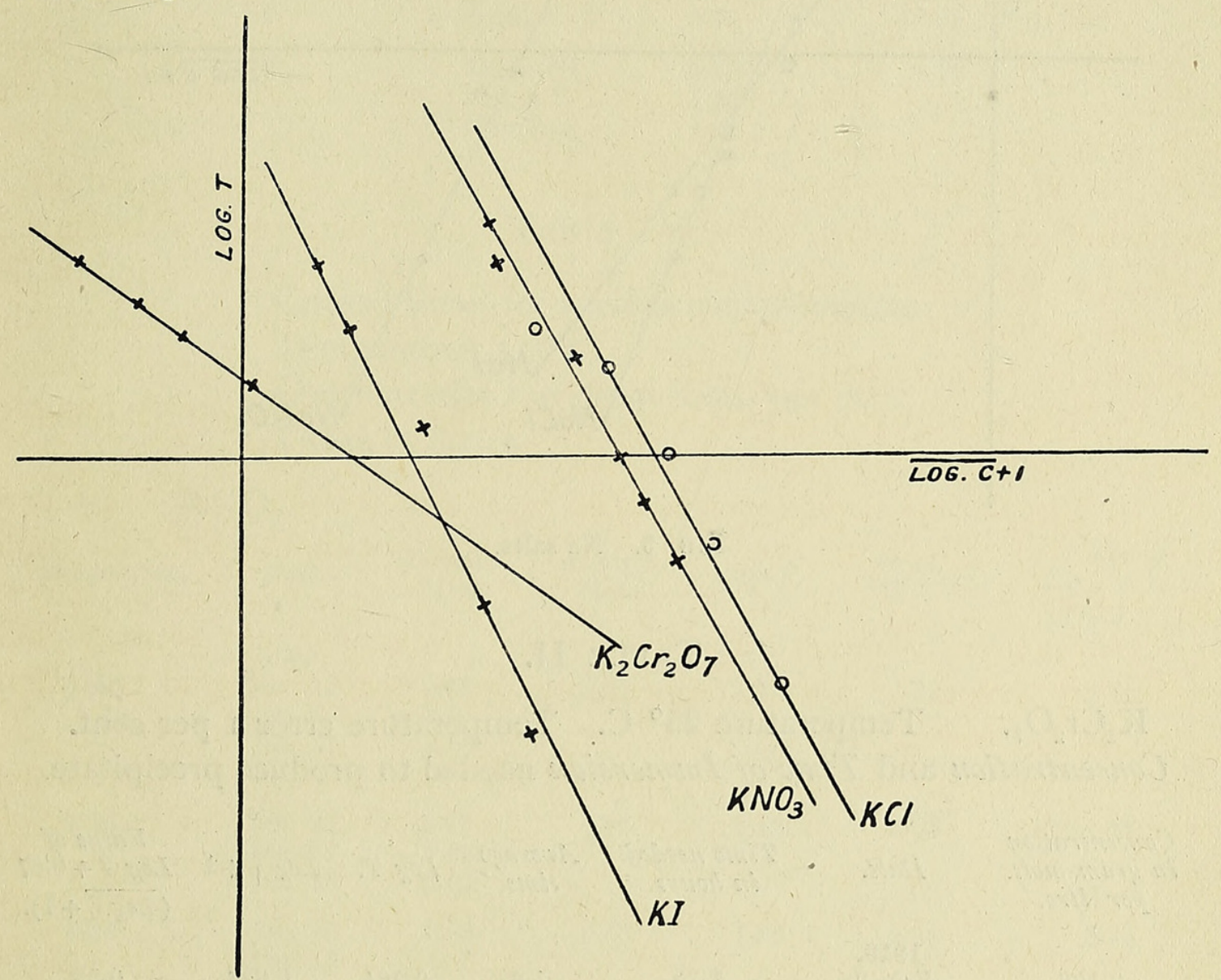

FIG. 2. $K$ salts.

TABLE I.

Resistance of O.I per cent. solution $\mathrm{K}_{2} \mathrm{Cr}_{2} \mathrm{O}_{7}$.

Electrodes $=$ platinized plates.

$\begin{array}{cccc}\text { Date. } & \begin{array}{c}\text { Age of } \\ \text { Solution }\end{array} & \begin{array}{c}\text { Temperature of } \\ \text { Thermostat. }\end{array} & \begin{array}{c}\text { Mean value of } \\ \text { Resistance. }\end{array} \\ \text { 1918. } & \text { Days. } & \text { Degrees Centigrade. } & \text { Ohms. } \\ \text { July } 31 & 0 & 25 & 428.7 \\ \text { Sept. } 2 & 33 & 25 & 429 \\ \text { Sept. } 4 & 35 & 24.95 & 424.9 \\ \text { Sept. } 9 & 40 & 25 & 428.7 \\ \text { Sept. } 11 & 42 & 24.95-25 & 428.3\end{array}$




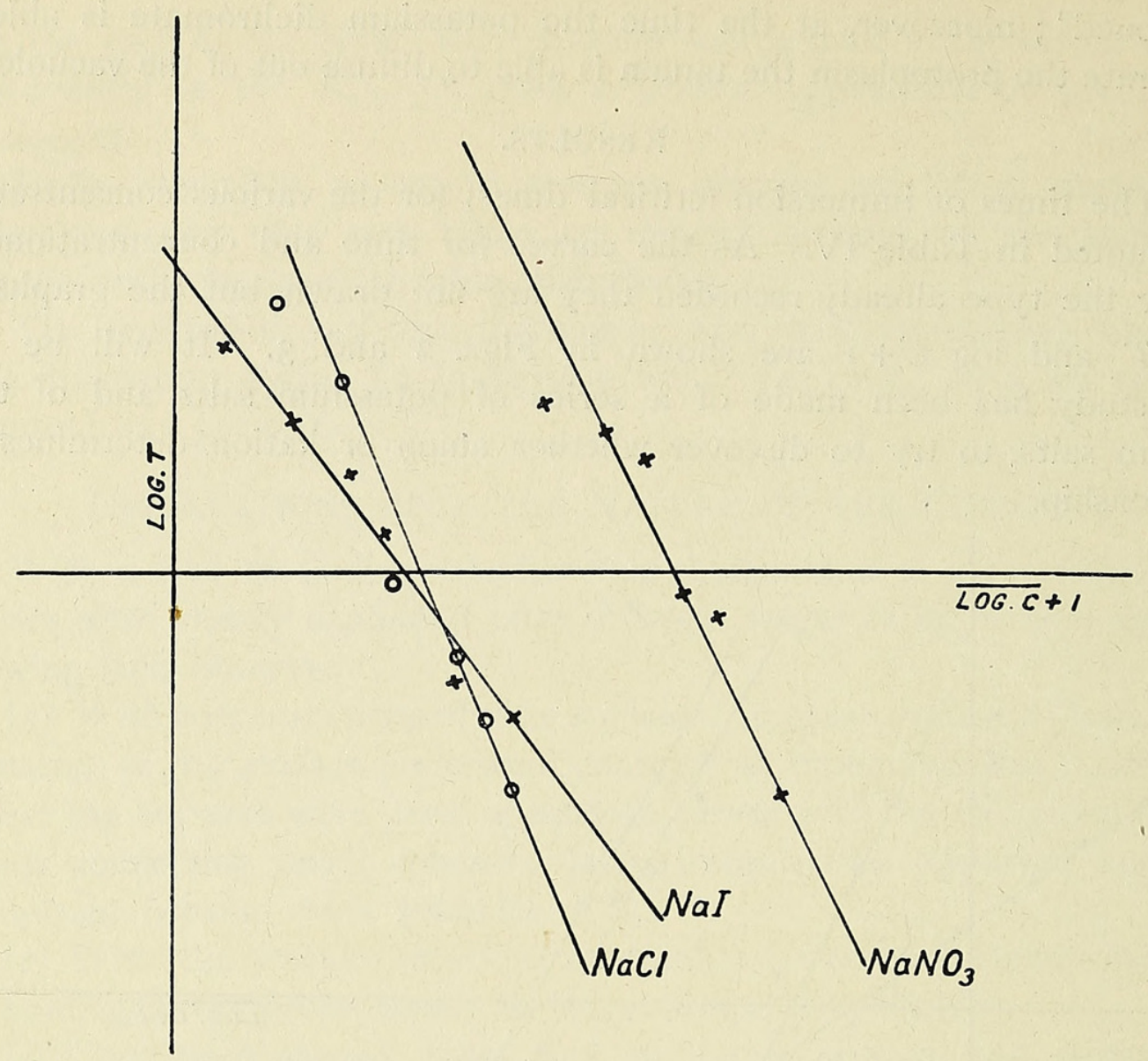

FIG. 3. Na salts.

TABLE II.

$\mathrm{K}_{2} \mathrm{Cr}_{2} \mathrm{O}_{7}$. Temperature $25^{\circ} \mathrm{C}$. Temperature error I per cent. Concentration and Time of Immersion needed to produce precipitate.

\begin{tabular}{|c|c|c|c|c|c|c|}
\hline $\begin{array}{c}\text { Concentration } \\
\text { in gram-mols. } \\
\text { per litre. }\end{array}$ & Date. & $\begin{array}{l}\text { Time needed } \\
\text { in hours. }\end{array}$ & $\begin{array}{l}\text { Average } \\
\text { time. }\end{array}$ & $\log T$ & $\overline{\log C}+1$ & $\begin{array}{c}\text { Value of } \\
\log T+0.67 \\
(\log C+1) .\end{array}$ \\
\hline 0.108 & $\begin{array}{l}1919 . \\
\text { Feb. } 28 \\
\text { Feb. } 28 \\
\text { March } 7\end{array}$ & $\begin{array}{l}1.75 \\
1.5 \\
1.66\end{array}$ & 1.6 & 0.204 & 0.033 & 0.23 \\
\hline 0.072 & $\begin{array}{l}\text { April } 4 \\
\text { April } 4\end{array}$ & $\begin{array}{l}2.16 \\
2\end{array}$ & 2.08 & 0.318 & $\overline{1} \cdot 837$ & 0.21 \\
\hline 0.054 & $\begin{array}{l}\text { March } 12 \\
\text { March } 13 \\
\text { March } 27\end{array}$ & $\begin{array}{l}2.5 \\
2.75 \\
2.75\end{array}$ & 2.66 & 0.425 & $\overline{1} .73$ & 0.24 \\
\hline 0.036 & $\begin{array}{l}\text { March } 28 \\
\text { April } 3 \\
\text { April } 3\end{array}$ & $\begin{array}{l}3.25 \\
3.25 \\
3.5\end{array}$ & 3.33 & 0.522 & $\overline{1} .536$ & 0.23 \\
\hline
\end{tabular}

Average value of constant in last column $=0.23$. Maximum deviations rom average $=+4 \%$. 


\section{TABLE III.}

Time of immersion required and temperature. Salt : potassium dichromate 3 per cent.

\begin{tabular}{|c|c|c|c|}
\hline Temperature. & Date. & Time. & Average Time. \\
\hline $\begin{array}{c}\text { Degrees Centigrade. } \\
25\end{array}$ & $\begin{array}{r}1919 . \\
\text { Feb. } 28 \\
\text { Feb. } 28 \\
\text { March } 7\end{array}$ & $\begin{array}{c}\text { Hours. } \\
1.75 \\
1.5 \\
1.66\end{array}$ & 1.6 \\
\hline 13.3 & $\begin{array}{l}\text { March } 7 \\
\text { March } 13\end{array}$ & $\begin{array}{l}3 \\
3.5\end{array}$ & 3.25 \\
\hline 9 & April 2 & 3.75 & 3.75 \\
\hline 0 & $\begin{array}{l}\text { March } 21 \\
\text { March } 27 \\
\text { March } 28\end{array}$ & $\begin{array}{l}4.75 \\
4.25 \\
4.75\end{array}$ & 4.58 \\
\hline
\end{tabular}

TABLE IV.

Critical times for various concentrations.

Temperature $25^{\circ} \mathrm{C}$.

Concentrations in gram-mols. per litre.

Times in hours.

A. $\mathrm{KNO}_{3}$.

$\begin{array}{ccccc}\text { Concentration. Date. } \quad \begin{array}{c}\text { Critical Average } \\ \text { Time. }\end{array} \text { Time. } & \log T . \quad \overline{\log C}+1 . \quad \begin{array}{c}\text { Value of } \\ \log T+1.77 \\ (\overline{\log C}+1) .\end{array}\end{array}$

\begin{tabular}{|c|c|c|c|c|c|c|}
\hline 1.42 & $\begin{array}{l}1920 . \\
\text { Jan. } 14 \\
\text { Jan. } 27 \\
\text { Jan. } 27 \\
\text { Feb. } 2\end{array}$ & $\begin{array}{l}0.42 \\
0.5 \\
0.66 \\
0.5\end{array}$ & 0.52 & $\overline{1} .72$ & 1.15 & 1.75 \\
\hline 1.19 & $\begin{array}{l}\text { Jan. } 20 \\
\text { Jan. } 21 \\
\text { Jan. } 26\end{array}$ & $\begin{array}{l}0.75 \\
0.83 \\
0.75\end{array}$ & 0.77 & $\overline{1} .89$ & 1.07 & 1.78 \\
\hline 0.98 & $\begin{array}{l}\text { Jan. } 13 \\
\text { Jan. } 13 \\
\text { Jan. } 14 \\
\text { Jan. } 14\end{array}$ & $\begin{array}{l}0.83 \\
1 \\
1 \\
1.08\end{array}$ & 0.98 & $\overline{1} .99$ & 0.99 & 1.74 \\
\hline 0.74 & $\begin{array}{l}\text { Jan. } 19 \\
\text { Jan. } 21 \\
\text { Jan. } 26\end{array}$ & $\begin{array}{l}2 \\
1.83 \\
1.66\end{array}$ & 1.83 & 0.26 & 0.87 & 1.79 \\
\hline 0.59 & $\begin{array}{l}\text { Jan. } 26 \\
\text { Jan. } 27 \\
\text { Feb. } 2 \\
\text { Feb } 2\end{array}$ & $\begin{array}{l}2 \\
2 \\
2.16 \\
2.16\end{array}$ & 2.08 & 0.32 & 0.77 & 1.68 \\
\hline 0.44 & $\begin{array}{l}\text { Feb. } 11 \\
\text { Feb. } 11 \\
\text { Feb. } 18\end{array}$ & $\begin{array}{l}4.25 \\
4.25 \\
4.25\end{array}$ & 4.25 & 0.63 & 0.64 & 1.76 \\
\hline
\end{tabular}

Average value of constant in last column $=1 \cdot 75 . \quad$ Maximum deviations from average $=+2 \%$. 
B. $\mathrm{KCl}$.

\begin{tabular}{|c|c|c|c|c|c|c|}
\hline Concentration. & Date. & $\begin{array}{c}\text { Critical } \\
\text { Time. }\end{array}$ & $\begin{array}{c}\text { Average } \\
\text { Time. }\end{array}$ & $\log T$. & $\overline{\log C}+1$ & $\begin{array}{c}\text { Value of } \\
\log T+1.72 \\
(\overline{\log C}+1)\end{array}$ \\
\hline 2.7 & $\begin{array}{l}\text { Jan. } 6, ' 20 \\
\text { Jan. } 7, ' 20\end{array}$ & $\begin{array}{l}0.25 \\
0.25\end{array}$ & 0.25 & $\overline{1} .398$ & 1.43 & 1.86 \\
\hline 1.87 & $\begin{array}{l}\text { Dec. } 9 \text {, ' } 19 \\
\text { Dec. } 9, ' 19 \\
\text { Dec. } 15,{ }^{\prime} 19\end{array}$ & $\begin{array}{l}0.5 \\
0.58 \\
0.58\end{array}$ & 0.55 & $\overline{1} \cdot 74$ & 1.27 & 1.92 \\
\hline 1.44 & $\begin{array}{l}\text { Dec. } 15, ' 19 \\
\text { Dec. } 16, ' 19 \\
\text { Dec. } 16, ' 19 \\
\text { Dec. } 16, ' 19\end{array}$ & $\begin{array}{l}1 \\
1.08 \\
0.83 \\
1\end{array}$ & 0.98 & $\overline{1} .991$ & $1 \cdot 16$ & 1.99 \\
\hline 0.96 & $\begin{array}{l}\text { Dec. } 8 \text {, '19 } \\
\text {.Dec. } 9 \text {, '19 } \\
\text { Dec. } 10, ' 19\end{array}$ & $\begin{array}{l}1.5 \\
1.5 \\
1.75\end{array}$ & 1.58 & 0.199 & 0.98 & 1.89 \\
\hline 0.485 & $\begin{array}{l}\text { Dec. } 15,{ }^{\prime} 19 \\
\text { Jan. } 5, ' 20 \\
\text { Jan. } 6, ' 20\end{array}$ & $\begin{array}{l}3.25 \\
3.33 \\
3.08\end{array}$ & 3.22 & 0.508 & 0.69 & 1.70 \\
\hline
\end{tabular}

Average value of constant in last column $=1.87$. Maximum deviations from average $=+7 \%$. $-9 \%$.

\section{KI.}

\begin{tabular}{|c|c|c|c|c|c|c|}
\hline Concentration. & Date. & $\begin{array}{c}\text { Critical } \\
\text { Time. }\end{array}$ & $\begin{array}{c}\text { Average } \\
\text { Time. }\end{array}$ & $\log T$ & $\overline{\log C}+1$ & $\begin{array}{c}\text { Value of } \\
\log T+2.09 \\
(\log C+1)\end{array}$ \\
\hline 0.59 & $\begin{array}{l}1919 . \\
\text { Oct. } 27 \\
\text { Oct. } 28 \\
\text { Oct. } 29 \\
\text { Oct. } 29\end{array}$ & $\begin{array}{l}0.16 \\
0.25 \\
0.16 \\
0.16\end{array}$ & 0.18 & $\overline{1} .255$ & 0.77 & 0.86 \\
\hline 0.445 & $\begin{array}{l}\text { Oct. } 22 \\
\text { Oct. } 27 \\
\text { Oct. } 28 \\
\text { Oct. } 28\end{array}$ & $\begin{array}{l}0.5 \\
0.33 \\
0.5 \\
0.33\end{array}$ & 0.41 & $\overline{1} \cdot 613$ & 0.65 & 0.97 \\
\hline 0.3 & $\begin{array}{l}\text { Oct. } 15 \\
\text { Oct. } 28 \\
\text { Oct. } 28 \\
\text { Nov. } 23\end{array}$ & $\begin{array}{l}1.25 \\
1.33 \\
1.16 \\
1.25\end{array}$ & 1.24 & 0.093 & 0.477 & 1.09 \\
\hline 0.18 & $\begin{array}{l}\text { Oct. } 13 \\
\text { Oct. } 7 \\
\text { Oct. } 8 \\
\text { Oct. } 15\end{array}$ & $\begin{array}{l}2 \\
2.25 \\
2.25 \\
2.5\end{array}$ & 2.25 & 0.352 & 0.255 & 0.89 \\
\hline 0.15 & $\begin{array}{l}\text { Nov. } 3 \\
\text { Nov. } 3 \\
\text { Nov. } 23\end{array}$ & $\begin{array}{l}3.25 \\
3.5 \\
3.25\end{array}$ & 3.33 & 0.52 & 0.176 & 0.89 \\
\hline
\end{tabular}

Average value of constant in last column $=0.94$. Maximum deviations from average $=-8 \%$. D. $\quad \mathrm{K}_{2} \mathrm{Cr}_{2} \mathrm{O}_{7}$. See Table II. 


\section{TABLE IV (continued).}

E. $\quad \mathrm{NaCl}$.

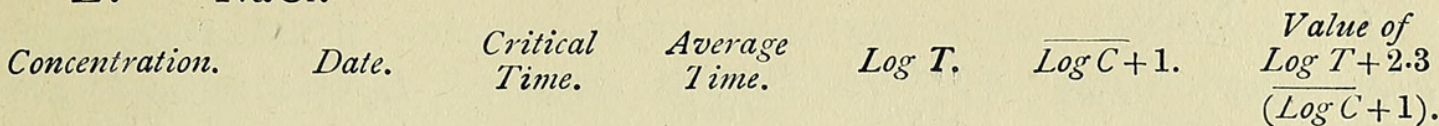
1919.

$0.68 \quad$ June 13

\begin{tabular}{ll} 
June 19 & 0.33 \\
\hline & 0.25
\end{tabular}

June $20 \quad 0.25$

0.59

July 17

July 28

July 29

0.51

June 26

June 27

July 3

0.34

June 13

June 13

June 19

June 20

0.255

July 3

July 4

July 4

July 28

$0 \cdot 17$

$\begin{array}{ll}\text { July } 28 & 4.5 \\ \text { July } 29 & 5 \\ \text { July } 29 & 4.75\end{array}$

0.4
0.4
0.33
0.66
0.66
0.5
0.83
0.75
1
1

0.37

$\overline{1} .57$

0.77

1.34

$0.61 \quad \overline{1} .78$

0.71

$1 \cdot 41$

$0.89 \quad \overline{1} .95$

0.53

1.17

2.9

0.46

0.41

1.40

2.5

4.5

$4 \cdot 75$

0.68

$0 \cdot 23$

1.18

Average value of constant in last column $=1.31$. Maximum deviations $=-10.6 \%$.

\section{F. $\quad \mathrm{NaI}$.}

Concentration.

Date. 1920 .

0.67

Sept. 21

Sept. 21

Sept. 24

Sept. 24

0.49

Sept. 6

Sept. 7

Sept. 9

$0 \cdot 33$

Sept. 7

Sept. 9

Sept. 22

0.26

Sept. 21

Sept. 21

Sept. 2.2

Sept. 22

0.2

Sept. 10

Sept. 10

Sept. 20

0.13

Sept. 20

Sept. 20

Sept. 27

Sept. 27
Critical Average

Time. Time.

0.42
0.42
0.42
0.42

0.5

0.42

0.58

\section{1}

1.25

1.25

1.75

1.66

1.75

1.66

$2 \cdot 25$

2.42

$2 \cdot 25$

3.83

3.66

3.5

3.75

$1 \cdot 7$
Value of

$\log T . \quad \overline{\log C}+1 . \quad \frac{\log T+1.38}{(\log C+1) .}$

$\begin{array}{llll}0.42 & \overline{1} .62 & 0.83 & 0.77\end{array}$

$0.5 \quad \overline{1} .7$

0.69

0.65

$\begin{array}{lll}1.17 & 0.07 & 0.52\end{array}$

0.79

0.23

0.42

0.81

$\begin{array}{lll}2.31 & 0.36 \quad 0.30\end{array}$

0.77

$3.68 \quad 0.57$

0.11

0.72

Average value of constant in last column $=0.75$. Maximum deviations $=+8 \%$.
$-13 \%$ 


\section{TABLE IV (continued).}

\section{G. $\quad \mathrm{NaNO}_{3}$.}

\begin{tabular}{|c|c|c|c|c|c|c|}
\hline Concentration. & Date. & $\begin{array}{l}\text { Critical } \\
\text { Time. }\end{array}$ & $\begin{array}{c}\text { Average } \\
\text { Time. }\end{array}$ & $\log T$. & $\overline{\log C}+1$ & $\begin{array}{c}\text { Value of } \\
\log T+1.91 \\
(\log C+1) .\end{array}$ \\
\hline 3.18 & $\begin{array}{l}1920 . \\
\text { June } 8 \\
\text { June } 14 \\
\text { June 14 }\end{array}$ & $\begin{array}{l}0.25 \\
0.25 \\
0.33\end{array}$ & 0.27 & $\overline{1} \cdot 43$ & 1.55 & 2.39 \\
\hline 2.18 & $\begin{array}{l}\text { June } 2 \\
\text { June } 2 \\
\text { June } 6 \\
\text { June } 6\end{array}$ & $\begin{array}{l}0.75 \\
0.75 \\
0.83 \\
0.75\end{array}$ & 0.77 & $\overline{1} .87$ & 1.34 & $2 \cdot 49$ \\
\hline 1.88 & $\begin{array}{l}\text { June } 15 \\
\text { June } 16 \\
\text { June } 22\end{array}$ & $\begin{array}{l}0.83 \\
0.83 \\
0.83\end{array}$ & 0.83 & $\overline{1} .92$ & 1.27 & 2.34 \\
\hline 1.37 & $\begin{array}{l}\text { May } 26 \\
\text { June } 30 \\
\text { June } 30\end{array}$ & $\begin{array}{l}1.83 \\
1.75 \\
1.92\end{array}$ & 1.83 & 0.26 & 1.14 & $2 \cdot 46$ \\
\hline 1.13 & $\begin{array}{l}\text { June } 29 \\
\text { June } 29 \\
\text { June } 30\end{array}$ & $\begin{array}{l}1.92 \\
2.16 \\
2.16\end{array}$ & 2.08 & 0.32 & 1.05 & 2.36 \\
\hline
\end{tabular}

Average value of constant in last colurnn $=2.41$. Maximum deviations $=-3 \%$. $+3 \%$.

\section{TABLE V.}

Formula : $\log T+k \overline{(\log C}+\mathrm{I})=K$.

Potassium salts.

\begin{tabular}{lcc}
\multicolumn{1}{c}{ Salt. } & $k$. & $K$. \\
Potassium iodide & 2.09 & 0.94 \\
Potassium nitrate & 1.77 & 1.75 \\
Potassium chloride & $\mathbf{1 . 7 2}$ & 1.87 \\
Potassium dichromate & $\mathbf{0 . 6 7}$ & 0.23
\end{tabular}

Sodium salts.

$\begin{array}{lll}\text { Sodium iodide } & 1.38 & 0.75 \\ \text { Sodium nitrate } & 1.91 & 2.41 \\ \text { Sodium chloride } & 2.3 & 1.31\end{array}$

\section{Discussion OF REsults.}

In each case graphs between $\log T$ and $\overline{\log C}+\mathrm{I}$ have been made and the points found to lie approximately upon straight lines. From the intercepts of these lines upon the axes the values of ' $k$ ' have been found.

In the last column of Table IV the value of ' $k$ ' has been substituted in the equation for each salt and the value of the second constant $K$ calculated. The ranges of deviation have been shown.

It will be seen that the time range was limited as it was not possible to run the thermostat through the night. In a few cases, where long-period experiments were made, a tendency was found for the change in the 
protoplasm to take place earlier than the calculated time. This tendency had already been found in experiments in dilute solutions at room temperature, but it took place with more concentrated solutions at $25^{\circ} \mathrm{C}$. than was the case at the lower temperature. The equations shown are therefore only suggested as applying for a time range of ten minutes to four hours at this temperature. Table $\mathrm{V}$ shows the constants collected for the series of potassium salts and for that of sodium salts. It will be seen that ' $k$ ' varies from 0.67 to 2.3 , while $K$ lies between 0.23 and $2.4 \mathrm{I}$. It is possible that the percentage error could have been reduced by still more care in selecting material so that there was greater uniformity in thickness of the cell walls, as this must have been a factor influencing the diffusion. It is interesting to examine the constants in the similar equation already found by other workers. In the work of Harvey (3) upon Chlamydomonas immersed in resorcin of various concentrations, the criterion used was cessation of movement. In this case ' $k$ ' was $\mathrm{I} \cdot 2 \mathrm{I}$, while $K$ ' had a value between 3.75 and $3.5^{8}$.

In the paper of Watson (2) the figures obtained by Chick for disinfection of bacteria were examined. Here the arbitrary measure of change was loss of power to multiply. 'The liquids used were phenol, silver nitrate, and mercuric chloride. The co-efficient ' $k$ ' had values from 0.86 to 5.5 for different substances, while the constant $K$ fell between 3 and 6.8 .

In the paper of Harvey it is stated that the equation in question is one obeyed in a chemical reaction where one molecule of one compound reacts with ' $k$ ' molecules of another compound, which is present in great excess, when the concentration ' $C$ ' is made to vary and $T$ is the time for the reaction to reach completion in each case. In the results recorded here it is clear that equimolecular solutions of two salts with monovalent kations and similar anions produce different effects, while marked differences occur if the kation be kept constant and the anion varied, so that simple chemical action does not seem to explain the changes produced. Of recent years great interest has centred round the absorption of ions by colloidal matter and consequent precipitations owing to electrical effects. The proteins of protoplasm are known to fall into the collodial category.

Precipitations of colloids by electrolytes show many complications. There is a tendency for increased adsorption as the valency increases, but valency alone is not enough to consider. Wilder Bancroft (5) suggests there is 'specific adsorption' so that the concentration of a given electrolyte necessary to neutralize the charge upon a given colloid depends upon the nature of both kation and anion. According to Hardy (6) when we deal with living: matter, or with organic compounds with large molecules, the influence of the electrolyte is determined not only by the charge carried by the ion but by the volume of the ion also. Further, precipitation 
experiments carried out in test-tubes give different values according to the speed with which the electrolyte is added and according to the amount of agitation.

No theory can at present be put forward to account for the formula obtained in the experiments described, but there are certain facts, set out below, which seem to indicate that the poisonous action of these strong solutions of salts is bound up with adsorption of ions and coagulation of colloids of the protoplasm.

I. The value of ' $k$ ' for the potassium salts, beginning with the smallest, runs in the order

dichromate < chloride < nitrate <iodide,

while the order of precipitation values for potassium salts acting upon colloidal iron oxide is found by Weiser and Middleton (7) to be exactly the same.

II. When experiments were made with salts of aluminium it was found far weaker concentrations sufficed to produce the critical change in a given time than sufficed with either potassium or sodium salts.

III. Deviations from the equation occur with the more dilute solutions, comparatively greater action taking place than with stronger solutions; these deviations seem comparable with those found for dye taken up from baths of different strengths by colloidal matter (8).

When the constants for sodium salts are examined it is curious to find that the co-efficient values, using different anions, run in exactly the reverse way to those found for potassium. It is interesting to find that in experiments by Pauli on anion adsorption by albumin cases were found where, in $\mathrm{HCl}$ concentration of $0.0 \mathrm{I} \mathrm{N}$ to $2 \mathrm{~N}$, the order of anion adsorption was reversed (5). With a view to finding simpler time relationships for coagulation of the colloids by electric charges it seems helpful to study a case in which charges of one kind only are used, instead of using an electrolyte where one may have negative ions, positive ions, and undissociated molecules. At the present time experiments are being made upon the same plant material under the action of radium. When the latter is contained in a platinum tube the $a$-rays, carrying positive charges, are cut out, and the plant cells can be submitted to the action of the $\beta$-rays, which carry negative charges. An endeavour is being made to connect time of action needed to produce the change in permeability with the intensity of radiation. There may possibly be certain effects to be allowed for due to the very 'hard' $\mathrm{X}$-rays which accompany the $\beta$-rays.

Further light perhaps may be thrown upon the action of the salts by carrying out experiments with one particular electrolyte over a range of temperatures and finding the changes in $k$ and $K$. It may also prove helpful to carry out experiments expressing results in terms of electric conductivities of solutions instead of molecular concentrations. 


\section{SumMary.}

I. Experiments upon changes produced in cells of Saxifraga umbrosa by immersion in certain electrolytes have been repeated and extended. Times of immersion necessary to produce a certain arbitrary change, viz. permeability to $0 \cdot \mathrm{I}$ per cent. $\mathrm{K}_{2} \mathrm{Cr}_{2} \mathrm{O}_{7}$, have been found for different concentrations of various salts.

2. The change of permeability referred to in this and earlier work has been shown to be irreversible and to indicate damage to or 'poisoning' of the cell.

3. The importance of immersion experiments at a fixed temperature has been shown.

4. The equation $\log T+k(\overline{\log C}+\mathrm{I})=K$,

where $T=$ time of immersion needed to produce the change,

$C=$ concentration in gram-mols. per litre,

has been shown to hold in the cases examined for periods up to four hours for immersions at $25^{\circ} \mathrm{C}$.

5. This equation obtained for vegetative cells of an angiosperm poisoned by immersion in solutions of sodium and potassium salts has been found to agree in form with that obtained by other workers for disinfection of bacteria and for poisoning of Chlamydomonas by other chemicals.

6. The constant $K$ and the coefficient $k$ depend upon the salt used, and equimolecular solutions do not produce equal effects. Evidence is put forward in favour of the view that the action of the strong solutions employed is connected with the adsorption of ions and consequent precipitation of colloidal matter.

7. The need for study of the action of one kind of charge alone is shown and the suggestion made that the investigation of the action of the $\beta$-rays of radium may throw light upon the course of events.

In conclusion, the writer wishes to express her sincere thanks to Professor W. Stiles for certain references, to Sir Archibald Reid, K.B.E., C.M.G., for his generous loan of a large amount of radium for the present experiments, and to Mr. F. J. Harlow, in whose department the work has been carried out, for his kindness in arranging for the necessary apparatus and for his invaluable advice and criticism throughout the experiments.

The Sir John Cass institute. 


\section{BIBLIOGRAPHY.}

1. Wili.iams, M. : The Influence of Immersion in certain Electrolytic Solutions upon Permeability of Plant Cells. Ann. Bot., Oct., I9i 8.

2. Watson, H. E. : A Note on the Variation of the Rate of Disinfection with Change in the Concentration of the Disinfectant. Journ. of Hygiene, I908.

3. Harvey, H. W.: The Action of Poisons on Chlamydomonas and other Vegetable Cells. Ann. Bot., I 909.

4. Dekker, J.: Über die physiologische Bedeutung des Gerbstoffs. Rec. trav. bot. néerlandais, I-60, I917.

5. Bancroft, W.: Neutralization of Absorbed Ions. Journ. of Phys. Chem., I9I5.

6. Hardy, W. B. : Problems of Living Matter. Proc. of Phys. Soc., vol. xxviii, Part II, i9i 6.

7. Weiser and Middleton: Adsorption by Precipitates. Journ. of Phys. Chem., Jan., I920.

8. Report of the British Association, p. 40, 1917. 


\section{$2 \mathrm{BHL}$ Biodiversity Heritage Library}

Williams, Maud. 1922. "On the influence of immersion in certain electrolytes upon cells of Saxifraga umbrosa." Annals of botany 36, 563-576. https://doi.org/10.1093/oxfordjournals.aob.a089824.

View This Item Online: https://www.biodiversitylibrary.org/item/234428

DOI: https://doi.org/10.1093/oxfordjournals.aob.a089824

Permalink: https://www.biodiversitylibrary.org/partpdf/319061

\section{Holding Institution}

Smithsonian Libraries

\section{Sponsored by}

Biodiversity Heritage Library

\section{Copyright \& Reuse}

Copyright Status: Not in copyright. The BHL knows of no copyright restrictions on this item.

This document was created from content at the Biodiversity Heritage Library, the world's largest open access digital library for biodiversity literature and archives. Visit BHL at https://www.biodiversitylibrary.org. 